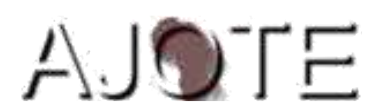

African Journal of Teacher Education

ISSN 1916-7822. A Journal of Spread Corporation

Volume 10. No. 12021 Pages 282-306

\title{
Classroom Process and Causes of Worsening High School Students' Performance in Literature-in-English in Nigeria
}

\author{
Eucharia Okwudilichukwu Ugwu \\ University of Ibadan, Nigeria.
}

\begin{abstract}
Current theories of teaching favour students-centred classrooms. In Literature-in-English lessons, active participation of students is essential for optimal learning. This study examined the level of students' active participation in Literature-in-English classrooms as the major reason for the high failure rates of Nigerian students who take this subject in the yearly senior secondary school examinations. The study was carried out in Ibadan metropolis, Oyo State. The mixed method research design was adopted. Class Observation Schedule $(r=0.9)$ and Interview Guide for Teachers were used to gather the data. Random sampling technique was used to select three Local Government Areas (LGAs), 27 public senior secondary schools (9 from each LGA) and one Literature-in-English teacher from each school. All the teachers were observed twice during lessons while 12 of them were interviewed. Results from the quantitative data showed that the classroom process was teacher-dominated, and students' level of participation was very low. Students hardly asked questions and teachers did not use teaching techniques that encouraged active participation. Teachers identified students' inability to buy the prescribed literary texts, lack of interest in reading and poor language proficiency as some of the factors that contribute to students' failure. Several recommendations were made to enhance the teaching-learning process and maximize learning.
\end{abstract}

Keywords: Teaching-learning process, Literature-in-English, examination failure, active participation, student-centred lessons

\section{Introduction}

Literature-in-English is taught in Nigerian senior secondary schools for several objectives, including cultural awareness, enhancement of language skills, personal development and adequate preparation of students for the school certificate examinations (Nigerian Educational 
Research and Development Council, NERDC, 2009). It is taught as drama, prose and poetry selected from African and non-African literary texts. Teachers are expected to enrich the content of their teaching with "relevant materials and information from their immediate environment" (NERDC, p. i).

Despite the rich and broad objectives set in the school curriculum, the level of students' engagement with and mastery of Literature-in-English is very low. For three consecutive years, (2017-2019), less than 25\% of them got a credit (A1-C6) in the West African Senior School Certificate Examination (WASSCE). The qualitative reports of the West African Examination Council (WAEC) Chief Examiner on students' performance indicate that the situation is deteriorating on yearly basis. The recurring high rate of failure points to specific problems in the teaching-learning process which limit students' learning. Urgent and adequate interventions are needed if the trend is to be reversed. If not, Literature-in-English may become an endangered school subject in Nigeria.

In view of the above premise, this study examined the teaching-learning process in Literature-in-English classrooms. How instruction is delivered can influence students' learning and achievement. The study also investigated teachers' view on the causes of worsening students' failure of Literature-in-English in the standard examinations.

\section{Background to the Study}

Although Literature-in-English is classified in the Nigerian senior secondary school as a core subject for arts students, it is actually a cross-cutting subject that is beneficial to every student, especially due to its linguistic potentials. Literature is language in operation, (Widdowson, 1979). It is basically a manipulation of language for self-expression which may take the form of storytelling (prose), dialogue (drama) or outpouring of feelings and emotions (poetry). To study Literature-in-English therefore, is to engage in the appreciation of the beauty of language. Whether students are engaged in reading, appreciation, analysis or classroom discussion of literary texts, they are invariably exploring the use of language by writers. Therefore, an engagement with each literary genre is equally an exposure to a particular way in which language has been used. Thus, students who study Literature-in-English can enhance their language skills.

Language is a tool for almost every learning activity in the school. By improving their language skills, students would be able to maximise their learning experiences. Besides, studying Literature-in-English can help them to form the habit of extensive reading and as well enhance their speaking, listening, writing, analytical and critical thinking skills. Close reading 
of literary texts can help students to build their vocabularies needed for improved writing and comprehension.

The world has become a global village in which people are easily connected through an effective use of language in different domains. Consequently, English has become a major world language and students must be able to communicate effectively in it to be able to find their rightful places in the society. Engaging students in dramatic performance, debating activities and writing competitions (as Literature-in-English teaching strategies), for example, could enhance their communicative competence, ability to work in team and self-confidence. Students need these skills to prepare for employment and life after school.

The close connection between Literature-in-English and language makes the former a useful pedagogical tool in ESL (English as a second language) classrooms around the world. Studies have shown that literature is very useful in gaining higher proficiency in English language (Anka, Ibrahim \& Yabo, 2017). According to Maley (2001), Literature-in-English is useful in EFL (English as a foreign language) and ESL classrooms due to its many qualities, including universality (cross-cultural themes), personal relevance and variety (language and subject matters), interest (familiar subject matters that could appeal to all), economy and suggestive power (evocative meaning of words and sentences). Literature also has the quality of ambiguity which gives every literary work a diversity of meanings. Thus, students have opportunities to interpret it differently and exchange ideas freely without fear of rejection.

The values of Literature-in-English also include personal growth and cultural awareness. The senior secondary school curriculum recommends that in the selection of texts, teachers should ensure that there is a balanced representation of African and non-African writings with a variety of themes (NERDC, 2009). Exposure to literary works from different parts of the world and written at different times in history could widen students' horizon and expand their thoughts and experiences. Cultures, observed Drucker (2015), are built on stories such as myths, legends, fables and religions, and if students are to understand and participate in the culture to which they belong, they must learn such stories.

Through Literature-in-English, students can learn some basic and timeless lessons of life such as courage and strength, patience and tolerance, social justice, empathy, and how to deal with human weaknesses and failures. These could help them to better understand or share in the universality of human experiences and acquire different skills needed to respond to life's recurring challenges. In prose and drama particularly, students encounter different characters in familiar and unfamiliar settings. Accordingly, literature enables students to enter into a 
multiplicity of worlds, a vast variety of people, cultures, places in reality and beyond, defying the boundaries of time and space (Rankhambe \& Patil, 2016). Students are expected to examine the realities of life presented in the literary texts they read, discuss, critic, interpret them and even expand such realities or ideas in the light of their own life experiences and social milieu.

Literature is also a form of entertainment. It gives pleasure to writers and the readers as well. Many literary writers use it as a channel to express or expand their experiences, emotions and feelings. Those who read the works vicariously share in those experiences. Moreover, one of the objectives of teaching Literature-in-English at the senior secondary school level is to enable students become creative writers. Engaging in creative writing could help students to develop their imaginative and creative potentials.

However, attaining the goals and enjoying the many benefits of Literature-in-English does not come automatically to students. They need to possess adequate mastery of the components of each genre. They also need to develop basic critical thinking, analytical and language skills needed for literary appreciation, interpretation and criticism. In view of that, how teachers deliver the lesson is important. Students cannot develop the skills on their own. Teachers, therefore, need to use teaching strategies that would actively engage them so that they would enjoy the lesson, contribute to the learning process, and arrive at a deeper level of comprehension. Without that, students may resort to rote learning.

In Nigeria, a major and standard way to measure students' level of mastery of any school subject (at the senior secondary level) is through their performance in the senior school certificate examinations (SSCE). However, evidence from the West African Senior School Certificate Examination (WASSCE) results points to a very shallow understanding of Literature-in-English among Nigerian students. In recent years (2017-2019), over 75\% of them failed Literature-in-English yearly and the few that pass hardly get high scores. Available statistics (Table 1) indicates that the situation is getting worse.

Table 1: Distribution of Nigerian students' Literature-in-English grades in the WASSCE (2017-2019)

\begin{tabular}{|l|l|r|r|r|r|r|l|l|l|l|l|}
\hline \multirow{3}{*}{ Year } & \multicolumn{10}{|c|}{ Trades obtained and Percentage } \\
\cline { 2 - 12 } & $\begin{array}{l}\text { Total } \\
\text { Registered }\end{array}$ & A1 & B2 & B3 & C4 & C5 & C6 & & P7 & P8 & F9 \\
\hline 2017 & 448070 & 0.0 & 0.1 & 1.6 & 2.0 & 3.7 & 16.0 & $\mathbf{2 3 . 7 7}$ & 17.6 & 20.7 & 32.76 \\
& & 3 & 3 & 7 & 7 & 6 & 8 & & 9 & 2 & \\
\hline
\end{tabular}




\begin{tabular}{|c|c|r|r|r|r|r|r|r|r|r|c|}
\hline 2018 & 457251 & 0.0 & 0.0 & 1.6 & 1.9 & 3.8 & 17.0 & $\mathbf{2 4 . 5 7}$ & 19.4 & 20.9 & 32.74 \\
& & 2 & 9 & 5 & 8 & 0 & 0 & & 0 & 0 & \\
\hline 2019 & 461266 & 0 & 0.0 & 0.9 & 1.5 & 3.3 & 16.2 & $\mathbf{2 2 . 1 7}$ & 18.9 & 21.2 & 35.41 \\
& & & 3 & 8 & 1 & 4 & 7 & & 1 & 4 & \\
\hline Tota & $1,366,587$ & \multicolumn{4}{|c|}{$\mathbf{1 . 5 \%}$} & & $\mathbf{2 1 . 8 \%}$ & $\mathbf{2 3 . 2}$ & $\mathbf{3 9 . 3 \%}$ & $\mathbf{3 3 . 4}$ \\
1 & & & & & & & & $\%$ & & & $\%$ \\
\hline
\end{tabular}

Source: The WAEC Report

As shown on Table 1, a total of 1,366,587 students registered Literature-in-English within three years (2017-2019). Compared to the huge number, only a few got a credit, that is, A1-C6, which is the required minimum standard. The number of students that sat for the examination increased yearly, but without a corresponding increase in the number of those that passed. For example, 2019 has the highest number of students but the least number of those that passed. The yearly distributions are as follows: 2017(23\%), 2018(24\%) and 2019(22\%) respectively. Moreover, within the three years, only $1.5 \%$ got between A1-B3 and $21.8 \%$ got between C4C6 (making a total of 23.3\%). Those that got F9 $(33.4 \%)$ is by far, higher than those that got a credit. The same thing is applicable to those that got P7-P8 (39.3\%).

The WAEC Chief Examiner's qualitative reports (Table 2) also indicate a downward trend in students' performance in the last 12 years (2009-2019).

Table 2: Summary of Chief Examiner's General Comments on Students' Performance in Literature-in-English (2009 - 2019)

\begin{tabular}{|l|l|l|}
\hline \multirow{2}{*}{ Year } & \multicolumn{2}{|c|}{ General Comments on students' performance } \\
\cline { 2 - 3 } & \multicolumn{1}{|c|}{ Paper 2 (Prose) } & Paper 3 (Drama and Poetry) \\
\hline 2009 & Below standard, compared to previous years & As low as previous years \\
\hline 2010 & No improvement, compared to previous years & No improvement \\
\hline 2011 & No improvement & No improvement \\
\hline 2012 & No improvement & No improvement \\
\hline 2013 & Very poor & Poorer than the previous year \\
\hline 2014 & Lower than last year & No improvement \\
\hline 2015 & Average performance & No improvement \\
\hline 2016 & Slight improvement & Improvement \\
\hline 2017 & No improvement & A decline \\
\hline
\end{tabular}




\begin{tabular}{|l|l|l|}
\hline 2018 & No improvement & A decline \\
\hline 2019 & A decline & A decline \\
\hline
\end{tabular}

Source: The WAEC, 2021

As shown on Table 2, there were slight improvements only in 2015 and 2016. However, the last three years (that is, 2017-2019) were worse, especially in drama and poetry (Paper 3). As a way forward, the Chief Examiner made some recommendations, including the need to provide the recommended literary texts for students, retrain teachers for improved teaching and learning, encourage students to cultivate good reading habit and discourage them from relying on the abridged versions of the texts. In spite of the recommendations made, not much has changed, as shown on the reports. It appears that there are still underlying problems that inhibit students' learning or that the identified ones have not been properly addressed.

\section{Literature Review}

For effective Literature-in-English instruction, there should be active participation of students. As Nurindah and Akil (2019) aptly put it, effective literary instruction requires that students be "good readers, good listeners and good responders". If any of the three components is missing, there could be problems in the teaching-learning process and the objectives of the lessons may not be attained. Granath (2017) stressed the need to make Literature-in-English "more exciting and relatable to students". Teachers, therefore, need to direct and monitor the classroom process by ensuring students' active participation. Teaching and Learning Centre (n.d) states that "fostering students' active involvement in their own learning increases what is remembered, how well it is assimilated, and how the learning is used in new situations".

However, fostering active participation of students in the classroom is a challenge to many teachers (Cothran, 2000; Oranu \& Onwioduokit, 2012; Mpho, 2018; Otara, 2019). Studies have shown that teachers' use of poor teaching strategies that do not actively engage students is prevalent in Nigeria (Ugwu, 2019a). Many teachers use the lecture method of teaching which is teacher-centred, does not create much opportunity for students to be actively involved, and therefore, is ineffective (Anyanwu, 2015; Busari, 2007; Danner and Musa, 2019). The lecture method of teaching presents the teacher as the provider and processor of knowledge, and therefore, at the centre of the classroom process.

Students will learn better if they, with their teachers, play complementary and collaborative roles in the classroom process. According to Weimer (2011), active participation of students can be used to increase students' interest, engage them to think, provide feedback to teachers and students, control the class, make students to be prepared before coming to class, 
build cordial relationships and provide opportunities for language practice. Stressing on the need for active participation of students in the classroom process, Cothran (2000) notes that even quality curriculum delivered "by a knowledgeable teacher will not result in student learning unless students first are engaged in the learning process". Active participation also helps to create a sense of satisfaction and opportunities for formative assessment (Kramer, 2016).

Across different school subjects and levels of education, experimental studies on the use of teaching methods that actively engage students yielded positive outcomes in terms of increased interest, motivation, retention, achievement, and critical thinking ability (Cothran, 2000; Nelson and Crow, 2014; Owodunni, 2015; Ezeokoli \& Igubor, 2016; Bergmark \& Westman, 2018; Tasgin and Tunc, 2018; Ugwu, 2019a; Ugwu, 2019b; Ezurike \& AyoVaughan, 2020). Students who are active in the class may be more able to synthesise, question, analyse and internalise their learning experience than the passive ones. In Literature-in-English lessons, active students may understand and appreciate the literary texts better and relate it to real life situations. Kramer (2016) suggests that active participation goes beyond asking of questions and calling on few students to respond. It is rather, ensuring that all students are involved in activities that are 'directly related to the content' of instruction.

The role of teachers is paramount in creating active and engaging classes. Cothran (2000) found that "engaging classes were characterised by teachers who were enthusiastic about their subject matter". Anyanwu (2015) is of the opinion that teachers need to plan class activities which focuses on identifying students' tasks that lead to learning rather than teachers' tasks for presenting the lesson. Therefore, how the lesson is planned is central to creating active and engaging atmospheres during lessons.

There are numerous instructional strategies that can be used to actively engage students during instruction. Walker (2003) lists questioning techniques, class discussion, debate and written assignment (in-class and out-of-class). Teachers can also adopt different cooperative and collaborative learning strategies that encourage group learning and presentation, peertutoring, peer and self-assessments. Two cooperative learning strategies (student teamsachievement division and think-pair-share) were found to enhance students' interest and achievement in reading comprehension (Ugwu 2019a; Ugwu, 2019b). Drama is also an effective teaching strategy that can actively engage students. Students who were exposed to dramatic activities developed more positive attitude to and achievement in the dramatic genre (Gorjian, Moosavinia and Jabripour, 2010; Fakeye and Adebiye, 2015; Bello and Offorma, 
2017). Engagement in peer assessment was also reported to increase students' positive attitude, rate of retention and achievement in English language and Mathematics, (Adeyemo, 2014; Oluseyi, 2014; Asuai and Adeleye, 2013 and Adediwura, 2015). Students who engage in peer and self-assessment may be more disposed to take personal responsibility for their learning as they learn to give and receive constructive and immediate feedback and develop basic formative assessment skills. Literature-in-English teachers who adopt any of these strategies could increase the level of students' active participation, enhance learning and reduce the chances of failure.

Given the many benefits of students' active participation in the classroom process, it is expected that Literature-in-English teachers' would use instructional strategies that encourage it, in other to maximize students' learning. On the contrary, if their preferred strategies do not actively engage students, the latter may not learn adequately and therefore, may not be able to pass their examinations.

\section{Research Question:}

1. To what extent are Literature-in-English students actively engaged in the classroom process?

2. What are teachers' views on the causes of students' failure of Literature-in-English in the senior secondary school examinations?

\section{Theoretical Framework}

The transactional model of reading propounded by Lousie Rosenblatt in 1978 is relevant in understanding the need for students' active involvement during Literature-in-English lessons. The model considers reading as a dynamic and an active process of making meaning from a text. The transactional model places learners at the centre of any reading exercise or instruction. It is built on the premise that there is a reciprocal and mutually defining relationship between the students and the literary text (Robertson, Sterling \& Rork, 1995). As such, students' previous experiences are important attributes needed for meaningful reading, literary appreciation, analysis, criticism, and classroom discussions. Reading is seen as a form of mutual transaction between the readers and the text which then gives birth to meaning.

During reading, Literature-in-English students, as active participants in the meaningmaking process, are expected to use their active thought process to enrich the interpretation of the text. Since human experiences are dynamic and literary texts have no single meaning, students may interpret a particular text differently. Therefore, the more they participate 
actively, the richer the textual interpretation would be. However, it is the duty of the teacher to ensure that students are actively engaged by challenging them to ask useful questions and also by providing opportunities that would make them play active roles in the class. Before classroom instructions, teachers need to prepare activities that would actively engage students. It may be in form of questions, assessment or student-centred teaching strategies.

\section{Research Method}

The study was carried out in the Ibadan metropolis, Oyo State, Nigeria. Random sampling technique was used to select three out of the five local government areas (LGAs) in the metropolis, 27 public senior secondary schools (9 from each LGA) and one Literature-inEnglish teacher from each school (making a total of 27 teachers).

The study adopted the mixed method research design. Two instruments: Class Observation Schedule ( $r=0.9$ ) and Structured Interview Guide for Teachers (SIGT) developed by the researcher were used to gather qualitative and quantitative data. Using the first instrument, each teacher was randomly observed twice during lessons to find out students' level of active participation. Teachers were not pre-informed before each observation. This was to ensure that they do not alter their normal teaching processes. A total of 54 lessons on prose, poetry, drama and literary appreciation were observed. The classes were SS1-3. Secondly, a total of 12 teachers in 12 schools (4 from each LGA) were interviewed.

The quantitative data were analysed using the descriptive statistics while the qualitative data were content analysed.

\section{Results and Discussion}

Research question 1: The extent of Literature-in-English students' active engagement in the classroom process

Table 3: Distribution of student-based activities during Literature-in-English Lessons

\begin{tabular}{|c|l|c|c|c|c|c|}
\hline \multirow{2}{*}{ S/n. } & \multicolumn{2}{|c|}{ Student-based Activity (SBA) } & \multicolumn{3}{|c|}{ No. of SBA per Genre Taught } & Total \\
\cline { 3 - 7 } & & $\begin{array}{c}\text { Prose } \\
(17)\end{array}$ & $\begin{array}{c}\text { Poetry } \\
(20)\end{array}$ & $\begin{array}{c}\text { Drama } \\
(13)\end{array}$ & $\begin{array}{c}\text { Literary } \\
\text { Appreciation (4) }\end{array}$ & $\begin{array}{c}54 \\
\text { Lessons }\end{array}$ \\
\hline $\mathbf{1 .}$ & Students ask oral questions & $\mathbf{1}$ & $\mathbf{1}$ & $\mathbf{3}$ & 0 & $\mathbf{5}$ \\
\hline $\mathbf{2 .}$ & Students engage in group discussion or & 0 & 0 & 0 & 0 & 0 \\
\hline $\mathbf{3 .}$ & Students present individual works & 0 & 0 & 0 & 0 & 0 \\
\hline 4. & Students present group works & 0 & 0 & 0 & 0 & 0 \\
\hline $\mathbf{5 .}$ & Students engage in peer assessment & 0 & 0 & 0 & 0 & 0 \\
\hline
\end{tabular}




\begin{tabular}{|c|l|c|c|c|c|c|}
\hline $\mathbf{6 .}$ & Students engage in self-assessment & 0 & 0 & 0 & 0 & 0 \\
\hline $\mathbf{7 .}$ & Others: (Quiz, Debate, Drama, etc.) & 0 & 0 & 0 & 0 & 0 \\
\hline & TOTAL & $\mathbf{1}$ & $\mathbf{1}$ & $\mathbf{3}$ & $\mathbf{0}$ & $\mathbf{5}$ \\
\hline
\end{tabular}

Table 3 shows the summary of student-based activities during 54 Literature-in-English lessons. There were 17 prose, 20 poetry, 13 drama and four literary appreciation lessons respectively. Of all the student-based activities listed on Table 3, only one, that is, asking of oral questions by students, took place (minimally) - in one prose, one poetry and three drama lessons, making a total of 5 questions raised by students. Students did not engage in individual or group activities such as presentation, group discussion, collaborative or cooperative learning, peer assessment, self-assessment, quiz, debate or drama. This means that teachers did not use teaching strategies that promote active participation of students. Therefore, students were generally passive. In summary, the classroom process was teacher-centred and students' level of participation was very low.

\section{Teachers' views on the causes of students' failure of Literature-in-English}

Below is the content analysis of teachers' responses during the interview. These were categorised into eight subheadings. Teachers' names and their demographic information were removed to retain their anonymity.

\section{Students' inability or unwillingness to buy the prescribed Literature-in-English}

texts. All the teachers stated that most of their students do not have the recommended texts. Excerpts:

T1: Our students don't have textbooks at all. They don't even buy any of the Literature books we read in the class. The teacher can be the only one talking and reading during lessons. And there is no amount of cajoling or pressurising that would move them to buy the books, they don't believe in it.

T2: The major factor, I won't deceive you, is that they do not have the textbooks. If they have the texts, they would be able to read on their own. In a class of 30, it may just be five or three that would have the books. By the time they would rotate the texts among themselves, time for the class would have gone.

T3: The students don't buy books. Even when they are asked to make photocopies of the poems, they would not do that. The cost was just $\$ 100$ but they can afford to buy $\$ 500$ 
recharge cards. I reported them to the school authority and even to the PTA but that did not address the problem. You cannot give them assignment in that situation.

T4: Students are no longer reading and parents refuse to buy the textbooks, especially the primary texts.

As the above responses indicate, teachers link students' failure to their non-possession of the recommended texts. The response of T1 confirms the result of the classroom observation which shows that students' level of active participation is very low. Without actively engaging students, teachers do all the talking. While it is true that having the literary texts could enhance the teaching-learning process, student may still remain dormant in the class even if they have the texts. It is the teachers' duty to actively engage students by using appropriate instructional strategies and techniques. For example, in a situation where up to five students have the texts, teachers could divide them into 5 groups, assign a chapter of the book to each, and task them to read and make group presentations or to write individual summary of the chapter. This process can make the class more manageable, increase students' level of participation and enhance comprehension.

2. Poor attitude towards reading and inability to read: The teachers observed that students have poor reading habit; some are unwilling to read while others cannot read. Excerpts:

T5: Students are lazy to read voluminous literary texts. It scares them. It is when their external exams - WAEC and NECO are close that some of them start reading. Besides, most of them go for the review or abridged texts, even though some of the abridged texts have errors.

T6: You know, literature requires a lot of reading because we have so many texts. Some find it difficult to read; they just want the teacher to tell them everything.

T10: Students don't read, they come to the class without knowing anything about the text I want to teach. If students cannot read, there is nothing the teacher can do. Some don't even know why they are here; you have to remind them.

T9: The students don't cultivate the habit of reading. Literature is very wide and there is no way you can pass if you do not read the text. But most of them are so lazy to read; they don't even want to read. At times I would give them my own books and divide them into groups to read but still, they would not read.

T11: Students nowadays do not want to read. Imagine somebody in SS3 that has never read a novel. The reading culture is no longer there. Even if the government provides the 
textbook, the internet has taken over; the students would not read. They go to the internet

to play. They are not even interested in ebooks, rather, they watch movies.

The overriding issue in the above responses is the problem of reading. However, several subthemes could be established, including students' inability to read, laziness, lack of interest in and poor attitude towards reading, fear of reading voluminous or several literature texts, examination-centred reading and lack of focus. From these various responses, it is obvious that teachers tend to lay all the blames on their students. Their responses sound as if there is no way forward. If students cannot read at a senior secondary school level, teachers need to acknowledge the fact that they too have failed in their processional practices. Therefore, it is not enough to claim that students are not interested in reading. If students are not interested in reading, they would not come to school. Their being in school means that they want to learn and it is the duty of the teachers to ensure that they actually learn. There are many instructional strategies that teachers can use to enhance students' reading skills and also to motivate them to read. But, as the classroom process, (Table 3 ) indicates, many Nigerian teachers are yet to move from a teacher-centred to student-centred teaching. Although T9 claimed that she/he had used group reading strategy but that it did not yield the desired effect, it is not clear how the group reading was organised. There are principles guiding group learning or group works in the classroom which must be adhered to for the strategy to work. For example, if students are paired but without proper direction or monitoring, they may end up creating a noisy scene.

\section{Poor attitude toward literature, lack of motivation, aspiration and a sense of}

direction: Teachers stated that many students in arts lack motivation to studying in general. Excerpts:

T7: Many students perceive the arts class as a dumping ground. You may hardly find up to $30 \%$ of them willing to proceed to higher institutions after the secondary school.

T12: Some students do not see Literature as an important school subject. Many of them find it difficult to concentrate and read the text. They rather wait for the teacher to summarise the text for them. They do not want to spend time studying on their own.

T3: Some, I guess, don't know why they are in arts class. Perhaps, teachers just put them there because they cannot cope with science. Maybe they felt commercial class may be difficult for them, and then, there is nothing left. So, some are just there, they don't really know why. I remember asking an arts student: what do you hope to become in future, he said "a doctor". I said, "in arts class"? So, you can imagine the mind-set that such a student may bring into the literature class. 
T1: Many students in arts class just find themselves there, sometimes through peer influence. But they are not capable of studying arts. Maybe, they are supposed to be in another class but because of the peer influence, they believe they also can cope, but at the end of the day, they will not be able to cope.

The last respondent was further asked: how are students placed in the different field of study? Are they allowed to make their choices or it is the school authority that categorises them?

She responded: Schools do not necessarily pair students, but there are some requirements. It is like JS3 students entering the senior class, there are criteria, maybe they are to pass 5 credits, including English and Mathematics, and that will qualify them too. The way things are now, on my own, if I am given that opportunity, the children are to be scrutinised before being allowed into any class. But that is not always the case. There should be a room created for that.

A dominant issue in the above responses is that many students do not feel motivated to study Literature-in-English due to several reasons. Some were "pushed" into the field of arts or chose to be there without proper guidance or orientation, not knowing what it entails or what to expect. Some think that the arts discipline has nothing to offer them; thus, they see their situation as a dead-end. However, in a situation where students cannot read, do not have the reading texts and are mere listeners in the class, it is not likely they will enjoy the lesson. If students do not enjoy the lesson, their level of motivation will also likely not going to be high. Although the causes of students' lack of motivation are multifaceted, teachers are probably not doing enough to motivate them. Thus, this problem still has a link to the classroom process. If students engage in dramatic performance rather than reading a drama text, for example, there would definitely be a higher level of excitement in the class and this can lead to increased motivation.

4. More emphasis on science disciplines: Some parents force their children to study science, irrespective of the children's interest or abilities. This may be due to the belief that science is more lucrative than arts in the job market. Excerpts:

T5: .... I will cite an example. I discovered a boy n SS3 who was so talented in arts. I asked him: how did you find yourself in a science class? You are supposed to be in arts class! What are you doing in Science? He said it was his father that insisted that he must study science and that it really affected him. So, for many of them, their problem emanated from parental factors. 


\section{Lack of concentration in school due to engagement in non-school related}

apprenticeship: This was emphasized in a particular local government area. This problem may be due to the limited job opportunities in Nigeria. Many students graduate without finding jobs and the available ones are very competitive. Children from poorer families may be more disadvantaged: they may not have opportunities like their counterparts from rich families. Parents seem to be aware of these dynamics; thus, they plan alternatives for their children so that after secondary education, they would not get stranded. However, combining schooling with apprenticeship makes students unable to concentrate in school. It could also affect their academic performance because they may not have enough time to study. Excerpts:

T9: Students don't have time to read, especially in this environment because most of them are learning trade. After school, they go to their masters' shops to learn. Almost $70 \%$ of them are learning trade, such as fashion designing, hair styling and selling of medicine. They do all these after school. Their parents are impatient because they believe that if they are through with SS3 and do not perform well in the final examination, they would switch to the job or business. But instead of giving them the full time to concentrate, they wouldn't do that.

T8: One thing that is rampart in this area is that we have a lot of students coping with both apprenticeship and education. Immediately they leave school each day, they go to their places of work or shops and get home late in the evening.

T7: Even those who have the textbooks have no time to read. Some of them, when they get home, have to do one or two things for the upkeep of the family.

T10: In this part of the town, they have different localities with different attitudes to education. Like in this area, would I say that most parents are poor and most students come from very poor background.

6. Government's policy: Building on the free education policy (which in theory, is obtainable in Nigeria but in practice, is not always the case), the present Oyo State Government distributes free exercise and textbooks to students in public secondary schools at the beginning of each academic year. Included in the distribution are textbooks on core science subjects. Literature-in-English teachers feel that the government has not been fair to arts students. They expect that since Literature-in-English is a core arts subject, the government should distribute some of the recommended literary texts to arts students just as it does to science students. Moreover, some parents misunderstand the concept of 'free education'. They think that if education is free, it means that the government would provide all the learning resources for 
their children. With that mindset, they fail to provide their children's basic educational needs. Excerpts:

T1: Parents are not cooperating, especially this time that we are in the era of free education.

T5: The government promised to give free books. They gave books on other subjects but none on literature. And, we have been told that no teacher should collect a dime from the students or ask them to buy books. The parents too who should be wise and augment the government's efforts by buying the remaining text - since the government have bought up to nine books for the students, are not ready to do anything.

T9: Parents are not ready to give students what they need.

T2: Most of the students do not have the prescribed texts and you cannot send them out of the class; you just have to do as the government wishes.

7. The nature of Literature: Some teachers pointed out that the language of literature, especially poetry, is difficult for students. This may be due to their limited proficiency in English language. As pointed out earlier, some students cannot read. However, this problem further establishes the negative effect of teacher-centred lessons in which students are not actively engaged. Students will most likely engage in rote learning if they do not understand the lesson. Excerpts:

T3 Most students find poetry very difficult because they cannot interpret the poem, they can memorise it but find it difficult to interpret or bring out the literary devices.

8. Heavy workload and problems with teachers' levels of commitment: Some teachers found their workload too heavy, especially those teaching both English language and literature. One of them stated:

T7: The workload is too much. In our school, it is only me, and it is not only literature that I am teaching.

During the class observation sessions, it was found that some teachers often missed classes. Each time, they gave different excuses such as having to attend to other needs. Teachers who miss classes may not cover the curriculum contents. If that happens, they may put the blame on too much workload or large number of literary texts they are required to teach, just as one teacher expressed:

T4: The texts, that is, the three genres, are many-it is impossible to teach all of them within a year. 


\section{Discussion of findings}

Teachers are the directors of the classroom process and the success of their work depends on how much students learn at the end of every lesson. If students fail examinations, it means that they did not learn adequately. It could also mean that teachers did not teach them well. On the other hand, adequate teaching and learning will increase students' chances of passing examinations. In Literature-in-English pedagogy, teachers and students have their respective roles to pay in the interpretive process. They are therefore, accountable for the success and failure of the classroom process. Consequently, teachers must ensure that students are not just receptors of abstract information or passive listeners but active collaborators in the classroom process. This requires that they use appropriate teaching methods and strategies that prompts students to think, speak, ask questions or engage in different planned activities.

However, what is obtainable in Literature-in-English classrooms, as the results of this study reveal, is that students are mostly passive during lessons. They hardly contribute to the teaching-learning process. Therefore, they rely solely on their teachers' interpretation of the literary texts. In almost all the lessons that were observed, teachers did all the talking while students played the roles of passive listeners. As a result, Literature-in-English lessons are boring, and it is difficult to gauge the level of students' learning. This is largely because the lessons are teacher-centred and not activity-based. One teacher paints a clear picture of what happens in the class: "If I am teaching prose, I will be the one reading, analysing for them, talking about the characters. ... It is so difficult. It is not making the subject interesting at all. ...". If the lessons are boring, students may not learn much. This problem is made complex by students' inability to buy or read the recommended texts. Without reading the texts, students come to the Literature-in-English class without prior or adequate preparation to participate in the teaching-learning process. Thus, one of the teachers said: the students would be looking as if they don't care. It may not be that the students do not care. It could be that they feel bored, are not motivated, or do not expect much from the lessons.

It is also important to note that ineffective classroom process, characterised by absence of students' participation cuts across the three genres of Literature-in-English. This indicates that there is a general problem in the teaching process. Teachers are not doing enough to actively engage their students. This agrees with the results of earlier studies which reported that Literature-in-English teachers use poor and ineffective teaching strategies (Kateregga, 2014; Ezeokoli, 2016; Danner \& Musa, 2019; Mubita \& Mwanza, 2020). 
If students' learning is to improve, teachers need to change their style of teaching by making it learner-centred and activity based. They need to use different teaching and assessment strategies that would promote active participation of all students, that would help to raise students' curiosity, and challenge them to ask questions in order to learn better. In a study by Debele and Kelbisa (2017), students' active participation in the class was improved through strategies like group discussion, jigsaw, peer-tutoring, pre-class reading assignments, creating friendly relationship with students and reducing lecturing time to accommodate more classroom activities. However, if teachers continue with the teacher-dominated lecture method of instruction, the situation may not change.

From the interview reports, teachers identified the following as factors responsible for students' failure of Literature-in-English: lack of textbooks, limited language proficiency which manifests in students' inability to read and poor attitude towards reading, lack of motivation, lack of concentration due to students' engagement in apprenticeship, inadequate support by the government and parents, and heavy workload. Another factor is teachers' inability to cover the curriculum content, sometimes due to their poor commitment to work.

Since Literature-in-English requires extensive reading, students who cannot read, or who dislike reading, may find it unappealing and difficult to understand. In Nigeria, low proficiency in English (which is a second language), may add to students' lack of interest in reading and by extension, low motivation to study or enjoy Literature-in-English. Students with limited proficiency in English language may not be able to read at a higher level of comprehension. This can demotivate or make them to avoid reading voluminous literary texts. Additionally, the distractive influence of the social media affects many students; as one of the teachers observed: students can afford to spend money on airtime but not on literary texts. Jurf (2012) emphasised that in the presence of the digital media devices, many readers no longer have the patience for storylines, characters, or plots but rather prefer emails, blogs, and many other digital inventions.

Extensive reading of literary texts can help students to generate and ask useful questions that may lead to deeper understanding. However, students' engagement in reading may depend on their ability to read and comprehend the text. Comprehension, observed Ugwu (2019b), "makes reading meaningful, interesting and worthwhile" (p. 221). Therefore, it is important for teachers to help students build their language skills. Teachers can take advantage of the various social media platforms and technological innovations to make reading more enticing to students. Since, according to one of the teachers, "the internet has taken over" students' 
attention, teachers need to exploit it for teaching-learning purposes. Dramatic and debating activities can also be used to boost students' self-confidence, speaking skills, teamwork and motivation to engage in literary appreciation and activities, all of which can enhance teaching and learning.

Another finding of this study is that students prefer reading the abridged versions of literary texts than the complete versions. This view is in line with Granath (2017) who reported that teachers were faced with unmotivated and uninterested students who preferred summarised versions of literary texts and Spark Notes. However, students' preference for the abridged version may also be due to their low language proficiency or lack of interest in reading. The prevalence of abridged versions of the recommended Literature-in-English texts and compiled past examination questions with ready-made answers have worsened the situation. One of the teachers pointed out that some of the abridged texts have errors. In spite of that, many bookshops in Nigeria have all kinds of summarised versions of literary texts and key points that claim to be the key to students' success in examinations. These could be so enticing to students, especially those with limited language proficiency and those who find reading uninteresting. In various WAEC Chief Examiners' reports, it was repeated that students' answers gave impressions that they read the abridged rather than the complete versions of the recommended texts (The WAEC, 2021).

Literature-in-English requires critical and close reading of the texts for better appreciation and deeper comprehension. Words and sounds are carriers of meaning in literary texts. Therefore, it is through reading that students encounter language in operation. In effect, reading the texts enables students to immerse themselves in the entire (and often captivating) storyline (in prose), the rich dialogues (in drama) and the beautiful sounds (in poetry). However, students who do not read the complete versions of the texts but rely solely on what their teachers teach in the class or on the abridged versions deny themselves of such opportunities to learn, to appreciate and to enjoy Literature-in-English. Such students will not be able to encounter words as used in the texts. In that case, they may not be able to learn new words and build their vocabularies, enhance their language skills and ask or respond to critical questions that could lead to a deeper level of literary criticism, interpretation and comprehension.

Reading the texts is fundamental to adequate learning of Literature-in-English. Literature-in-English, unlike some science subjects, has no set of formulas that can be memorised and used to analyse the texts or answer examination questions. Hence, knowing the 
full details of the storyline as told in the prose text, the beginning, unfolding of events and actions and their end in drama, and the dictions, sounds and even the arrangement of poetry stanza are fundamental to literary appreciation. If the story is retold, the essential parts may be lost. Therefore, teachers need to use every available means to ensure that students read the texts and enjoy the lessons for optimal learning.

\section{Recommendation}

To improve the teaching-learning process and reduce chances of student's' failure, the following are recommended:

i. Literature-in-English teachers need to be retrained on effective teaching methods and techniques that encourage learner-centred approaches to teaching.

ii. Given the high rate of students' failure which is getting worse each year, the government should, as a matter of urgency, wade into the problem, by either providing the recommended Literature-in-English texts to students or making them available in the school libraries so that students who are unable to buy their personal copies could have access to them.

iii. Students and their parents should be re-educated on the values of arts as a school subject and as an enriching discipline.

iv. School authorities should occasionally invite professionals in arts-related disciplines, including lawyers, journalists, established novelists and literary writers to address and educate students on promising career paths for arts students.

v. Students should be properly guided when they are choosing school subjects so that they will be able to make informed decisions based on their capacity, interest and passion.

vi. There is also a need for proper integration of vocational subjects in the senior secondary schools as stated in the National Policy on Education. If students are enabled to learn life skills while in school, their parents may not have cogent reasons for enrolling them in apprenticeship programs which end up distracting them.

vii. Extra-curricular activities such as debating societies, reading and writing clubs should be put in place in schools. Additionally, inter and intra school competitions and arts festivals should be organised periodically for students in those clubs. This may increase students' interest in and appreciation of Literature-in-English and encourage them to engage more in creative writing. 


\section{Conclusion}

Teachers' most important task in the classroom process is to ensure that students learn. Yet, the extent of learning is dependent on their ability to create learner-centred classrooms where students do not see themselves as spectators but as collaborators who also are responsible and accountable for their learning experiences. Therefore, the teaching-learning process cannot be one-sided. While teachers are the directors of the classroom process, students are at the centre. However, how teachers plan their lessons is fundamental to creating a learner-centred classroom where students can play their own roles. They need to use instructional strategies that have student-based activities and that would task them to play specific roles and contribute to the classroom process. These activities, when properly harnessed, will not only enhance Literature-in-English students' learning experience but could also make the classroom environment lively.

Different voices are needed in Literature-in-English lessons. When students do not participate or have a say, their voices are lost and the result could be rote learning. It is the teachers' duty to give a voice to their students and to ensure that they learn. However, this is far from the reality. The classroom process is teacher-dominated and teaching strategies that could promote students' participation are not used by teachers. In spite of that shortcoming, students are mainly blamed for failing to learn, for being lazy, for not having the books and for lacking in motivation.

In the teaching-learning process, teachers are like physicians in the hospital and students are their patients. Every patient who goes to the hospital would ordinarily want to get well. In the same way, students go to school so that they would learn and teachers must ensure that they actually learn. The major concern of every physician should be that the patient recovers. If a particular drug does not facilitate the healing process, the physician may rediagnose the patient or look for alternative drugs. The physician would not ordinarily blame the patient for not getting better. Therefore, to blame students for failing to learn adequately is like blaming the patients for not recovering. The present teacher-dominated style of teaching is not making students to learn. Teachers need to change their method of teaching.

A major limitation of this study is that the causes of students' failure in the examinations were considered only from teachers' own perspectives. It is like a one-sided story. Future studies might leverage on this gap by looking at the problem from students' own angle. 


\section{References}

Adediwura, A. A. (2015). Relationship between learning outcomes and peer assessment practice. European Scientific Journal, 11, 353-368.

http://eujournal .org/index.php/esj/article/view/5874

Adeyemo, E. O. (2014). Effect of teacher's guided students peer - assessment on teaching and learning in a large class. Mediterranean Journal of Social Sciences, 5, 296-301. http://dx.doi.org/10.5901/mjss.2014.v5n8p296

Anka, S. M., Ibrahim, H. A. \& Yabo, N. U. (2017). Integration of literature in language teaching at upper basic schools in Nigeria. The Victorian, 5(2), 80-86. https://www.semanticscholar.org/paper/Title-of-Paper\%3A-INTEGRATION-OFLITERATURE-IN-AT-IN-AnkaIbrahim/0ef17e3635219cb003aa4c355a44b8576d4ad06c

Anyanwu, S. U \& Fidelia N. Iwuamadi, F. N. (2015). Student-centered teaching and learning in higher education: Transition from theory to practice in Nigeria. International Journal of Education and Research, 3(8), 349-358. https://www.ijern.com/journal/2015/August-2015/29.pdf

Asuai, N. C. \& Adeleye, B. A. (2013). Impact of peer assessment on performance in mathematics among senior secondary school students in Delta State, Nigeria. Journal of Emerging Trends in Educational Research and Policy Studies, 4(5), 719-725. https://pdfs.semanticscholar.org/f63f /d9def8394e01d0240dc917b59446fdddfbe9.pdf

Bello, B. O. \& Offorma, G. C. (2017). Effect of Drama on Secondary School Students' Achievement in Family Life and HIV/AIDS Education Component of English Language Curriculum. Journal of the Nigerian Academy of Education, 8(2), 84-98. https://www.researchgate.net/publication/280554426_Effect_of_Drama_on_Secondar y_School_Students'_Achievement_in_Family_Life_and_HIVjAIDS_Education_Com ponent_of_English_Language_Curriculum

Bergmark, U. \& Westman, S. (2018) Student participation within teacher education: emphasising democratic values, engagement and learning for a future profession. Higher Education Research \& Development, 37(7), 1352-1365. https://doi.org/10.1080/07294360.2018.1484708 
Cothran D. J. (2000). Building bridges to student engagement: communicating respect and care for students in urban high schools. Journal of Research and Development in Education 33(2), 106-117. https://psycnet.apa.org/record/2000-07241-004

Danner, R. B. \& Musa, R. J. (2019). Evaluation of methods teachers use in teaching Shakespearean drama in senior secondary schools in Edo State. Journal of Teaching and Teacher Education, 7(2), 87-98. http://dx.doi.org/10.12785/jtte/070206

Debele, E. T. \& Kelbisa, E. M. (2017). The role of active learning methods for classroom participation: The case of first year students of sociology in Samara University. IOSR Journal of Humanities and Social Science, 22(7)13, 11-18. https://doi.org/10.9790/0837-2207131118.

Drucker, H. (2015). The importance of teaching literature. http://www.brighthubeducation.com/teaching-methods-tips/100744-the-importanceof-teaching-literature/

Ezeokoli, F. O. (2016). Perceived Effectiveness of Identified Methods and Techniques Teachers Adopt in Prose Literature Lessons in some Secondary Schools in Owerri. International Journal of Education and Literacy Studies, 4(3), 54-61. http://dx.doi.org/10.7575/aiac.ijels.v.4n.3p.54

Ezeokoli, F. O. \& Igubor, P. (2016). Effects of two methods of instruction on secondary school students' critical response to Prose Literature texts in English in some secondary schools in Benin City. International Journal of Languages' Education and Teaching, 4(2), 102-124. http://dx.doi.org/ 10.18298/ijlet.586

Ezurike, C. P. \& Ayo-Vaughan, A. F. (2020). Influence of teacher-centered and studentcentered teaching methods on the academic achievement of post-basic students in biology in Delta State, Nigeria. Teacher Education and Curriculum Studies, 5(3), 120124. https://doi.org/10.11648/j.tecs.20200503.21

Fakeye, D. O , Adebile, R. F. \& Toju, E. (2015). Participation in Literary Club Activities and Literature Instruction in a Dynamic and Evolving Society. International Journal of Educational Research and Technology, 6, 65-69. http://dx.doi.org/10.15515/ijert.0976-4089.6.3.6569

Fakeye, D. O. \& Adebile, R. (2014). Enriching literature-in-English instruction in the context of informal school literary clubs in Nigeria. Journal of Language and Cultural Education, 2(3), 25-36. $\quad$ http://files.jolace.webnode.sk /2000001912b8d42c85e/JoLaCE\%202014-3-002.pdf 
Gorjian, B., Moosavinia, S. R. \& Jabripour, A. (2010). Dramatic Performance in Teaching Drama in EFL Contexts. The Electronic Journal for English as a Second Language, 13(4), 1-13. https://eric.ed.gov/?id=EJ898206

Granath, S. (2017). Teaching literature in upper-secondary English class A qualitative study of Swedish teachers' approaches and experiences. Malardalen University, Sweden. Degree project ENA308. https://mdh.diva-portal.org/smash/get/diva2:1177161/FULLTEXT01.pdf

Jurf, D. R. M. (2012). Utilisation of digital media in improving children's reading habits. University of Bradford eThesis. https://bradscholars.brad .ac.uk/handle/10454/6299

Kateregga A. (2014). Towards a holistic approach of teaching and learning literature: Misconceptions about and endangerment of literature in Uganda's schools. Synergies Afrique des Grands Lacs, 3, 25-34. https://gerflint.fr/Base /Afrique_GrandsLacs3/Abubakar_Kateregga.pdf

Kramer, T. (2016). Teaching strategies for promoting active participation presented for Wright State University. https://www.wright.edu/sites /www.wright.edu/files/page/attachments/Tracey\%20Kramer\%20\%20TSSS\%202016\%20Teaching\%20Strategies\%20for\%20Promoting\%20Active\%2 OParticipation.pdf

Maley, A. (2001). "Literature in the Language Classroom." In R. Carter and D. Nunan (Eds.), The Cambridge Guide to Teaching English to Speakers of Other Languages (180-185). New York: Cambridge University Press.

Mpho, O. M. (2018). Teacher centered dominated approaches: Their implications for today's inclusive classrooms. International Journal of Psychology and Counselling, 10(2), 1121. https://doi.org/10.5897/IJPC2016.0393

Mubita, E. S. \& Mwanza, D. A (2020). Factors Contributing to Pupils' Poor Performance in Literature in English. International Journal of Humanities Social Sciences and Education, 7(3), 55-65. http://dx.doi.org/10.20431/2349-0381.0703007

Nelson, L. P. \& Crow, M. L. (2014). Do active-learning strategies improve students' critical $\begin{array}{lllll}\text { thinking? } & \text { Higher } & \text { Education } & \text { Studies, } & 4(2),\end{array}$ http://dx.doi.org/10.5539/hes.v4n2p77

Nigerian Educational Research and Development Council, NERDC, (2009). Federal Ministry of Education. Senior secondary school curriculum. Literature in English for secondary schools. NERDC: Abuja. 
Nurindah, Akil, M. \& Jafar, B. (2019). Teachers' Self-efficacy and Performance in Teaching Literature in the Interest-based Classes at Senior High School. Journal of Language Teaching and Research, 10(6), 1271-1278. http://dx.doi.org/10.17507/jltr.1006.16

Oluseyi, A. E. (2014). Effect of teacher's guided students peer - assessment on teaching and learning in a large class. Mediterranean Journal of Social Sciences, 5, 296-301. http://dx.doi.org/10.5901/mjss.2014.v5n8p296

Oranu, P. C. \& Onwioduokit, F. A. (2012). Relative effectiveness of classroom interaction techniques on students' participation in Rivers State, Nigeria. Journal of Educational and Social Research, 2(10), 81-88. https://doi.org/10.5901/jesr.2012.v2n10p81

Otara, A. Uworwabayeho, A. Wenceslas Nzabalirwa, W. \& Kayiseng, B. (2019). From ambition to practice: An analysis of teachers' attitude toward learnercentered pedagogy in public primary schools in Rwanda. SAGE Open, 1-11, https://doi.org/10.1177/2158244018823467

Owodunni, A. S. (2015). Influence of classroom interaction patterns on student achievement in basic electricity at technical colleges in Federal Capital Territory, Abuja. International Conference on 21st Century Education at HCT Dubai Men's College, UAE, 7(1), 144-153. https://www.21caf.org/uploads/1/3/5/2/13527682/144-153.owodunni.pdf

Rankhambe, V.A. \& Patil, P. F. (2016). Stylistic approach to the teaching of literature. International journal of multifaceted and multilingual studies, 3(12), 1-4. https://www.researchgate.net/publication/335571083_Stylistic_Approach_to_the_Tea ching_of_Literature

Robertson, A., Sterling, S., \& Rork, V. (1995). Transactional Reading. http://www.castle.eiu.edu/speebp/ppt/Reading--Transactional-Reading-PT.ppt.

Tasgin, A. \& Yunus Tunc, Y. (2018). Effective participation and motivation: An investigation on secondary school students. World Journal of Education, 8(1), 58-74. https://doi.org/10.5430/wje.v8n1p58

Teaching and Learning Centre. (n.d.). Small and large group teaching. Using class participation to develop student engagement. https://info.lse.ac.uk /staff/divisions/Teaching-andLearning-Centre/Assets/Documents/Using-class-participation-to-develop-studentengagement-FINAL.pdf

The West African Examinations Council. (2021, February 1). e-learning. Literature-in- 
English. https://waeconline.org.ng/e-learning/Literature/litEmain.html

Ubulom, W. J \& ogwunte, P. C. (2017). Evaluation of teacher-centered and learner-centered methods for instructional delivery of senior secondary schools financial accounting in Rivers State. International Journal of Innovative Finance and Economics Research 5(3), 81-88. https://seahipaj.org/journals-ci/sept-2017/IJIFER/full/IJIFER-S-82017.pdf

Ugwu, E. O. (2019a). Effect of student teams-achievement divisions and think- pair-share on students' interest in reading comprehension, Journal of Educational Research and Practice, 9(1), 316-330. https://doi.org/10.5590/JERAP.2019.09.1.22

Ugwu, E. O. (2019b). Effect of student teams achievement division and think-pair-share on students' achievement in reading comprehension. African Journal of Teacher Education, AJOTE 8(1), 218-237. https://doi.org/10.21083/ajote.v8i0.5209

Walker, S. E (2003). Active learning strategies to promote critical thinking. Journal of Athletic Training, 38(3), 263-267. https://www.ncbi.nlm.nih.gov/pmc/articles/PMC233182/

Weimer, M. (2011). 10 Benefits of getting students to participate in classroom discussions. https://www.facultyfocus.com/articles/teaching-and-learning/10-Benefits-of-gettingstudents-to-participate-in-classroom-discussions/

West African Examinations Council. (2017). Chief Examiner's Report. Yaba, Lagos.

West African Examinations Council. (2018). Chief Examiner's Report. Yaba, Lagos.

West African Examinations Council. (2019). Chief Examiner's Report. Yaba, Lagos.

Widdowson, H. (1979). Explorations in applied linguistics. Oxford: Oxford University Press. 